\title{
Etiology and haemato-biochemical alterations in cattle of J ammu suffering from anaemia
}

\author{
Jagpreet Singh, S. K. Gupta, Randhir Singh and S. A. Hussain
}

1. Department of Clinical Veterinary Medicine, College of Veterinary Sciences, Sher-e-Kashmir University of Agricultural Sciences and Technology of J ammu (SKUAST-J), R.S. Pura-181102, J \&K, India;

2. Department of I Veterinary Medicine, College of Veterinary Science, Guru Angad Dev Veterinary and Animal Sciences University, Ludhiana-141004, Punjab, India.

Corresponding author: Randhir Singh, email: dr. randhirlo@gmail.com

Received: 29-10-2013, Revised: 15-12-2013, Accepted: 19-12-2013, Published online: 04-02-2014

doi: 10.14202/vetworld.2014.49-51

How to cite this article: Singh J, Gupta SK, Singh R and Hussain SA (2014) Etiology and haemato-biochemical alterations in cattle of J ammu suffering from anaemia, Veterinary World 7(2): 49-51.

\begin{abstract}
Aim: To obtain the clinical appraisal and haemato-biochemical alterations in cattle suffering from anaemia in Jammu division of J\&K, India.

Materials and Methods: 125 cattle were screened for anaemia on the basis of Haemoglobin (Hb) concentration. Blood samples were taken for estimation of $\mathrm{Hb}$, packed cell volume (PCV), total erythrocyte count (TEC), mean corpuscular volume $(\mathrm{MCV})$, mean corpuscular haemoglobin $(\mathrm{MCH})$, mean corpuscular haemoglobin concentration (MCHC), total protein, albumin, total bilirubin, plasma iron and total iron binding capacity (TIBC). Faecal samples were screened for ova/ cyst and peripheral blood smear was examined for haemoprotozoa. The animals with $\mathrm{Hb}<8 \mathrm{~g} / \mathrm{dl}$ were categorized as anaemic.

Results: Out of 125 cattle screened for anaemia, 47 (37.6\%) were anaemic. Levels of Hb, PCV, TEC, MCH, MCHC and plasma iron were significantly lower in anaemic cattle than non-anaemic cattle while TIBC was significantly higher. The clinical signs in majority of the anaemic animals were depression, pale mucous membrane, dehydration and rough body coat. Faecal examination revealed parasitic infestation in 25 of those anaemic animals (Trichostrongyloids - 16 and Bunostomum09). Ticks were seen in seven animals, whereas three animals were lice/ flea infested. Peripheral blood smear examination revealed Babesia bigemina infection in five animals.
\end{abstract}

Conclusion: Hb, PCV, Plasma iron and TIBC were significantly altered in the present study and can be used for diagnosis of anaemia in cattle. The major causes of anaemia in this study were endo- and ecto-parasitic infestations.

Keywords: anaemia, cattle, parasitic infestation, TIBC

\section{I ntroduction}

Anaemia is functionally defined as decreased oxygen carrying capacity of blood $[1,2]$. This condition is clinically characterized by reduction in the haemoglobin $(\mathrm{Hb})$, haematocrit $(\mathrm{PCV})$ or total erythrocyte count (TEC) per unit volume of blood in a normally hydrated animal [3]. Anaemia in bovine is of great importance because of the direct and indirect economic losses. Direct economic losses are due to mortality and morbidity and indirect losses are in the form of reduced production [4-6]. Bovine anaemia occurs in three forms viz, haemorrhagic anaemia, haemolytic anaemia and anaemia due to reduced or defective erythropoiesis [7]. Haemolytic anaemia is encountered in the haemoprotozoan infections such as Theileriosis, Babesiosis and Rickettesial infections such as Anaplasmosis [8]. Bone marrow suppression has been reported by feeding of trichloroethylene, extracted soybean meal, arsenic, furazolidone and phenyl butazone $[9,10]$. There are no previous published reports on etiology and laboratory alterations in anaemia of cattle from Jammu, J\&K, India.

Copyright: The authors. This article is an open access article licensed under the terms of the Creative Commons Attribution License (http://creativecommons.org/licenses/by/2.0) which permits unrestricted use, distribution and reproduction in any medium, provided the work is properly cited.
So the present study was undertaken to obtain the clinical appraisal and haemato-biochemical alterations in cattle suffering from anaemia.

\section{Materials and Methods}

Study area: A total of 125 female cattle (105 adult and 20 heifers) presented during summer months (April to September) of the year 2011 at (a) Referral Large Animal OPD of F.V.Sc \& A.H, SKUAST-J, R.S.Pura, Jammu and (b) Military dairy farm, Belicharana, Satwari, Jammu, were screened for anaemia. The animals included local crossbreds in the age range 1.5 to 9 years.

Ethical approval: The study was conducted after the approval of the Institutional Animal Ethics Committee.

Sample collection: The blood samples were collected in EDTA coated vials, aseptically by jugular venipuncture. $\mathrm{Hb}, \mathrm{PCV}$, TEC, erythrocyte indices- mean corpuscular volume (MCV), mean corpuscular haemoglobin (MCH) and mean corpuscular haemoglobin concentration (MCHC) were estimated by standard methods as described by Weiss and Wardrop [9]. Total plasma protein was estimated by Direct Biuret method (Agappe diagnostic kits, AGAPPE, India), albumin was estimated by Bromocresol green method (Agappe diagnostic kits), total bilirubin was estimated by diazo 
Table-1. Age wise incidence of anaemia in the screened cattle

\begin{tabular}{lccc}
\hline $\begin{array}{l}\text { Age group } \\
\text { (Years) }\end{array}$ & $\begin{array}{c}\text { No. of animals } \\
\text { screened }\end{array}$ & $\begin{array}{c}\text { No. of anaemic } \\
\text { cattle }\end{array}$ & Percentage \\
\hline$<2$ & 20 & 6 & 30 \\
$2-4$ & 51 & 18 & -35.3 \\
$4-6$ & 35 & 15 & -42.9 \\
$>8$ & 19 & 8 & -42.1 \\
Total & 125 & 47 & 37.6 \\
\hline
\end{tabular}

Table-3. Biochemical parameters in non-anaemic and anaemic cattle (Mean \pm S.E)

\begin{tabular}{lcc}
\hline Parameter & Non anaemic $(\mathbf{n = 7 8 )}$ & Anaemic $(\mathbf{n}=\mathbf{4 7})$ \\
\hline $\operatorname{TPP}(\mathrm{g} / \mathrm{dl})$ & $7.82 \pm 0.096$ & $7.57 \pm 0.1$ \\
Albumin $(\mathrm{g} / \mathrm{dl})$ & $2.96 \pm 0.06$ & $2.72 \pm 0.06$ \\
A:G & $0.69 \pm 0.03$ & $0.55 \pm 0.02$ \\
Total bilrubin $(\mathrm{mg} / \mathrm{dl})$ & $0.57 \pm 0.04$ & $0.62 \pm 0.07$ \\
Iron $(\mu \mathrm{g} / \mathrm{dl})$ & $154.4 \pm 1.09$ & $102.6 \pm 3.95^{\star}$ \\
TIBC $(\mu \mathrm{g} / \mathrm{dl})$ & $369 \pm 7.55$ & $694.4 \pm 24.78^{*}$ \\
\hline
\end{tabular}

* Significantly differ at $\mathrm{p}<0.05$. TPP: total plasma protein, A:G: albumin globulin ratio, TIBC: total iron binding capacity

method as per manufacturers guidelines (Erba Mann Heim Pvt. Ltd kit, India), plasma iron and total iron binding capacity (TIBC) were estimated by use of iron binding capacity kit (Erba Mann Heim Pvt. Ltd kit, India). Normal value of $\mathrm{Hb}$ was taken as $8-15 \mathrm{gm} / \mathrm{dl}$ [9] and animals with $\mathrm{Hb}<8 \mathrm{~g} / \mathrm{dl}$ were categorised as anaemic. On the basis of laboratory analysis, the cattle were divided into two groups i.e., anaemic and nonanaemic. Blood smears from all the animals were examined for haemoprotozoan infections. Skin was examined for ectoparasites and faecal samples were examined for ova/ cyst.

Statistical analysis: The data was analysed by unpaired 't' test.

\section{Results}

Clinical observations: Out of 125 animals, 47 were anaemic and 78 were non-anaemic on the basis of laboratory analysis. The presenting clinical signs in anaemic cattle were depression $(n=32)$, pale mucous membranes $(n=26)$, dehydration $(n=11)$, sub normal temperature $(n=7)$ and rough body coat $(n=5)$.

Faecal examination and examination for ectoparasites: Out of 47 anaemic cattle, faecal samples of 25 animals were positive for ova/ cyst. Out of these 25,16 had Trichostrongylus spp. infestation and 9 had Bunostomum spp. infestation. Ectoparasites were present on ten animals being ticks in seven and lice/ fleas in three cases. The ticks identified were Boophilus spp. $(\mathrm{n}=4)$ and Rhipicephalus spp. $(\mathrm{n}=3)$.

Haematology: The age wise incidence of anaemia is presented in Table-1. The haemogram values of anaemic and non-anaemic cattle are presented in Table- 2 . The mean values of $\mathrm{Hb}, \mathrm{PCV}$, TEC, $\mathrm{MCH}$ and $\mathrm{MCHC}$ were significantly lower $(\mathrm{p}<0.05)$ in anaemic cattle than non anaemic cattle. The values of MCV did not differ significantly between the two groups. Peripheral blood smear examination revealed B. bigemina infection in 5 anaemic animals.
Table-2. Haemogram in non-anaemic and anaemic cattle (Mean \pm S.E)

\begin{tabular}{lcc}
\hline Parameter & Non anaemic $(\mathbf{n}=\mathbf{7 8})$ & Anaemic $(\mathbf{n}=\mathbf{4 7})$ \\
\hline $\mathrm{Hb}(\mathrm{g} / \mathrm{dl})$ & $9.73 \pm 0.16$ & $6.7 \pm 0.11^{*}$ \\
$\mathrm{PCV}(\%)$ & $31.15 \pm 0.058$ & $25.34 \pm 0.633^{*}$ \\
$\mathrm{TEC}(106 / \mu \mathrm{l})$ & $6.39 \pm 0.11$ & $5.46 \pm 0.13^{*}$ \\
$\mathrm{MCV}(\mathrm{fl})$ & $49.42 \pm 1.05$ & $47.29 \pm 1.42$ \\
$\mathrm{MCH}(\mathrm{pg})$ & $15.48 \pm 0.33$ & $12.66 \pm 0.30^{*}$ \\
$\mathrm{MCHC}(\mathrm{g} / \mathrm{dl})$ & $27.57 \pm 0.71$ & $31.72 \pm 0.58^{*}$ \\
\hline
\end{tabular}

* Significantly differ at $p<0.05$. Hb: Haemoglobin, PCV: packed cell volume, TEC: total erythrocyte count, MCV: mean corpuscular volume, $\mathrm{MCH}$ : mean corpuscular haemoglobin, MCHC: mean corpuscular haemoglobin concentration

Biochemical parameters: The mean value of total plasma protein, albumin, Albumin globulin ratio (A: G ratio) and total bilirubin did not differ significantly $(p<0.05)$ between anaemic cattle and non-anaemic cattle (Table-3). The mean value of plasma iron was significantly $(\mathrm{p}<0.05)$ lower in anaemic cattle than non-anaemic cattle, while TIBC was significantly higher $(\mathrm{p}<0.05)$ in anaemic cattle than non anaemic cattle.

\section{Discussion}

The major cause of anaemia in this study was endoparasitic infestation followed by ectoparasite infestation and blood protozoa. It has been previously reported that anaemia generally occurs due to blood protozoa and endo- and ectoparaites [11, 12]. It was interesting to note that, although seven animals had ticks on their body but only five of them were positive for haemoprotozoa i.e., Babesia bigemina. The cause of anaemia in other seven cattle could not be established and may be attributed to dietary factors [13]. The clinical signs in present study were similar to findings reported previously $[11,14]$. The observed variation in the incidence of anaemia among different age groups could be due to reasons like nutritional and managemental practices. Iron deficiency anaemia is common in young animals due to only milk feeding and small iron reserve [3].

The haematological findings were similar to earlier reports $[15,16]$, which mentioned the mean values of $\mathrm{Hb}, \mathrm{PCV}$ and TEC to be $7.56 \pm 0.68 \pm 0.70 \mathrm{~g} / \mathrm{dl}$, $24.06 \pm 2.20 \%$ and $4.97 \pm 0.61 \times 10^{6} / \mu 1$. However, further lower values of $\mathrm{Hb}(4.81 \pm 0.09 \mathrm{~g} / \mathrm{dl}), \mathrm{PCV}(18.27 \pm 0.06$ $\%)$ and TEC $\left(3.95 \pm 0.06 \times 10^{6} / \mu \mathrm{l}\right)$, had been reported by Khan et al. [15]. The reduction in mean $\mathrm{MCH}$ and MCHC could be due to direct reduction in the level of haemoglobin concentration which might be due to deficiency of iron $[15,17]$. The iron deficiency was confirmed by low iron levels in anaemic cattle. Contrary to the present study, low albumin and total plasma 
protein in anaemic herds has also been reported previously $[18,19]$. The cause in those studies has been attributed to the chronic low protein intake [20], decreased albumin synthesis by liver and hypergamma globulinemia due to chronic anaemia. Lower A: G ratio in anaemic cattle of present study may be due to decreased albumin level of anaemic cattle [19, 21]. Significantly $(p<0.01)$ lower level of plasma iron in anaemic cattle indicated iron deficiency anaemia. The iron deficiency anaemia may be attributed to endo- and ectoparasite infestation [22-24]. This decrease in plasma iron might be also due to rapid depletion of iron stores by the bone marrow for $\mathrm{Hb}$ production $[15,25]$. Low iron and high TIBC could be likely due to secondary iron deficiency which might be attributed to blood loss due to parasitic infestation $[8,11,18]$.

\section{Conclusion}

Out of 125 cattle screened, 47 (37.6\%) were suffering from anaemia. Anaemia is a multifactorial disease condition. However, in our study, the major cause of anaemia was endoparasitic infestation, especially by Trichostrongylus spp. Levels of $\mathrm{Hb}$, PCV, TEC, $\mathrm{MCH}, \mathrm{MCHC}$ and plasma iron were significantly lower in anaemic cattle than non anaemic cattle while TIBC was significantly higher in anaemic cattle than non-anaemic cattle.

\section{Authors' contributions}

The present study was part of JS's M.V.Sc. thesis. SKG designed the experiments and approved the experimental protocol. JS and RS drafted the manuscript. SAH did statistical analysis and critically reviewed the manuscript. All authors read and approved the final manuscript.

\section{Acknowledgements}

The authors are grateful to Dr J S Soodan, Head, Teaching Veterinary Clinics, Sher-e-Kashmir University of Agricultural Sciences and Technology of Jammu (SKUAST-J) for support during this study. The authors are thankful to Director of research, SKUAST-J for providing facilities and funds for the research.

\section{Competing interests}

The authors declare that they have no competing interests.

\section{References}

1. Morris, D. D. (2001) Alteration in Erythron. In Smith BP(ed) Large Animal Internal Medicine pp 419-428 Mosby Inc. Missouri, USA.

2. Goklaney, D., Singh, A.P., Dhuria, R.K. and Ahuja, A. (2012) Therapeutic Evaluation of Mineral Preparation for Amelioration of Anaemia in Goats of Arid Zone of Rajasthan. Iranian J. Appl. Anim. Sci. 2(2): 137-141.

3. Kahn, M.C. and Line, S. (2010) References guides. In: The Merck Veterinary Manual. $9^{\text {th }}$ edn. Published by Merck and Co. New Jersey, USA. page no. 2584-85.

4. Chavai, B.R., Ulmek, B.R., Asawalw, S.P. and Deokar, D. K. (2001) Studies on mortality pattern in crossbred cattle.
Indian J. Anim. Prod.Manag. 15: 82-83.

5. Terbalanche, H.J.I.J. (1979) Trials with febental to determine the affection breeding ewes and their offsprings. Vet. Med. Rev. 79: 118-125.

6. Zahid, I. A., Latif M. and Baloch. K. B. (2005) Incidence of endoparasites in exotic cattle calves. Pak. Vet.J. 25(1): 47-48.

7. Smith, J.F. (1997) Iron metabolism and its diseases. Clinical Biochemistry of Domestic Animals. pp 223-39. (Eds) Kaneko, J.J., Harvey, J.W. and Bruss, M.L. Academic Press, New York.

8. Soulsby, E.J.L. (1986). Helminths, Arthropods and Protozoa of Domesticated Animals. 7th Ed. The English Language Book Society, Bailliere Tindall, London, UK. page no. 28485.

9. Weiss, D. J. and Wardrop., K. J. (2010) Schalm's Veterinary Hematology. $6^{\text {th }}$ ed. Wiley-Blackwell. Page no. 8-11.

10. Stockham, S.L. and Scott, M. A. (2002). Fundamentals of Veterinary Clinical Pathology. pp 86-148. Iowa state press, 2121 state Avenue America, Iowa.

11. Radostits, O.M., Gay, C.C., Hinchcliff, K. W. and Constable, P. D. (2010) Veterinary Medicine: A Textbook of the Diseases of Cattle, Horses, Sheep, Pigs and Goats, $10^{\text {th }}$ edn. W.B. Saunders, London. Page no. 414-17.

12. Anwar, A.H., Hayat, C.S. and Amir, M.I. (1996) Prevalence of gastrointestinal helminthiasis and comparative efficacy of anthelmintics in parasitized buffalo calves. Pak. Vet. J. 16: 160-163.

13. Izzo, M.M, Poe, I., Horadagoda, N., De Vos, A.J. and Hous, J.K. (2010) Haemolytic anaemia in cattle in NSW associated with Theileria infections. Aus. Vet. J. 88(1-2):45-51.

14. Aulakh, G.S. and Singla, L.D. (2006) Clinicohaematobiochemical observations on bovines naturally infected with Theileria annulata. J. Vet. Parasitol. 20(1): 4952.

15. Khan, I.A., Khan, A., Hussain, A., Riaz, A. and Aziz, A. (2010) Hemato-Biochemical alterations in crossbred cattle affected with Bovine theileriosis in semi arid zone. Pak. Vet. J. 31(2): 137-140.

16. Bhardwaj, R.K., Randhawa, C.S., Randhawa, S.S. and Dhaliwal, P.S. (2010) Clinico-haemato-biochemical profile in chronic anemic crossbred cattle. Indian J. Anim. Sci. 80 (3): 220-224.

17. Cole, D.J., Roussel, A.J. and Whitney, M.S. (1997) Interpreting a bovine $\mathrm{CBC}$ : Collecting a sample and evaluating the erythron. Vet.Med 5: 460-68.

18. Katoch, A. and Mandial, R.K. (2003) Clinicohaematological,biochemical and therapeutic studies on anaemia in cattle. Indian J. Vet. Med. 23: 75-78.

19. Tufani, N.A., Hafiz, A., Malik, H.U., Peer, F.U. and Makhdoomi, D.M. (2009) Clinico-therapeutic management of severe anaemia in crossbred cow. Intas Polivet 1:53-55.

20. Morris, D.D. and Johnston. (2001) Alterations in blood proteins. Large Animal Internal Medicine. pp 429-32. (ed) Smith B P. Mosby Inc. Missouri, USA.

21. Coles, E.H. (1980) Veterinary Clinical Pathology. W.B. Sunders, Philadelphia pp. 106.

22. Gupta, P.P., Singh, B., Mandal, P.C., Gill, B.S. and Grewal, G.S. (1978) A postmortem study of mortality pattern in adult buffaloes in Punjab. Indian J. Anim. Sci.48: 669.

23. Rani, N.L., Sreedevi, C., Annapurna, P. and Kumar, K. A. (2010) Clinical management and haemato-biochemical changes In babesiosis in buffaloes. Buffalo Bulletin 29(2): 92-94.

24. Whitlock, R.H., Manston, R., Rowlands, J., Little,W. and Payne, J. M. (1976) Anaemia in dairy cattle: its incidence and relationship to the metabolic profile. Proceedings of third international conference on production diseases in farm Animals. Wageningen, the Netherlands, pp 61-63.

25. Schalm, O.W. (1975) Differential diagnosis of anaemia in animals. J. Am. Vet. Med. Assoc. 161: 1269-1275. 